\title{
Rapid and efficient leaf regeneration propagation system for Euonymus bungeanus
}

\author{
K. NING ${ }^{1,+}$, T. ZHOU ${ }^{2,+}$, C.Z. JIANG ${ }^{1}$, H.M. WU ${ }^{1}$, J.L. JIANG ${ }^{1}$, J. CHEN ${ }^{1}$, Y.A. El-KASSABY ${ }^{3, *}$, \\ and Y. MA ${ }^{1, *}$ \\ ${ }^{1}$ College of Horticulture, Jinling Institute of Technology, Nanjing 210038, P.R. China \\ ${ }^{2}$ Institute of Botany, Jiangsu Province and Chinese Academy of Sciences, Nanjing 210014, P.R. China \\ ${ }^{3}$ Department of Forest and Conservation Sciences, University of British Columbia, Vancouver, BC V6T 1Z4, \\ Canada
}

*Corresponding authors: E-mail: JITmayan@163.com,y.el-kassaby@ubc.ca

\begin{abstract}
Rapid propagation of plants by tissue culture is of great significance for large-scale production, molecular genetics research, and breeding. Currently, a rapid and high-efficient tissue culture protocol for Euonymus bungeanus is needed. To develop a propagation system for this species, we established a new regeneration system from leaves. Callus formation was induced on Murashige and Skoog (MS) medium supplemented with $0.5 \mathrm{mg} \mathrm{dm}^{-3}$ 6-benzylaminopurine (6-BA) and $0.5 \mathrm{mg} \mathrm{dm}^{-3} \alpha$-naphthalene acetic acid (NAA) and the induction rate almost reached $100 \%$ under red radiation within $21 \mathrm{~d}$. The medium for proliferation of adventitious buds comprised of MS medium with $1.0 \mathrm{mg} \mathrm{dm}^{-3}$ $6-\mathrm{BA}$ and $0.5 \mathrm{mg} \mathrm{dm}^{-3} \mathrm{NAA}$, and the induction rate within $20 \mathrm{~d}$ nearly reached $100 \%$. When, the adventitious buds were transferred to the rooting medium containing $1 / 2 \mathrm{MS}, 2.0 \mathrm{mg} \mathrm{dm}^{-3}$ indole-3-butyric acid (IBA), and $0.05 \mathrm{mg} \mathrm{dm}^{-3}$ NAA, adventitious root formation was achieved within $20 \mathrm{~d}$. Collectively, the rapid and high-efficient regeneration system from E. bungeanus leaves was established, providing useful references for effective mass propagation and it could serve as an enabling technology for future genetic engineering.
\end{abstract}

Keywords: adventitious buds and roots, 6-benzylaminopurine, callus induction, indole-3-butyric acid, $\alpha$-naphthalene acetic acid.

\section{Introduction}

Euonymus bungeanus is a small deciduous tree species native to northern China from the Heilongjiang province to Yangtze River and also is widely distributed in Ussuri region, southern Siberia, and Korean Peninsula (Liu et al. 2019). E. bungeanus has few pests and diseases and preferentially requires high irradiance but it is capable of surviving in harsh and extreme environmental conditions (Wang et al. 2016). The species unique growth characteristics (branch and crown shapes) increased its value for landscaping in southern China (Zhang et al. 2010). Moreover, the leaves of E. bungeanus are usually green in spring and summer, and in autumn the color of leaves turn red. Colored-leaf plants gain popularity in landscape architecture (Gang et al. 2019).

E. bungeanus is generally reproduced sexually through seed sowing and vegetatively propagated using rooted cuttings (Song and Ding 2013). However, the species largescale sexual reproduction is restricted for two reasons: complicated seed pretreatment and undesirable progeny characteristics resulting from mitotic genetic segregation (Xu et al. 2004). Similarly, propagation capacity through cuttings is also limited after the identification of desirable varieties. Contrary to the traditional propagation using seed and cuttings, propagation through tissue culture has several advantages owing to the outstanding qualities such as rapid propagation, scale-up, low cost, space-saving, and season-free characters (Smith and Jernstedt 1989). Furthermore, tissue culture has an enabling technology role

Received 5 June 2020, last revision 16 November 2020, accepted 25 November 2020.

Abbreviations: 6-BA - 6-benzylaminopurine; IBA - indole-3-butyric acid; MS - Murashige and Skoog; NAA - $\alpha$-naphthalene acetic acid. Acknowledgements: This work was financially supported by the Demonstration and Popularization of Industrial Planting Raising Technology of Color Leaf Salt-tolerant Tree of Euonymus bungeanus in Coastal Saline-alkali Land (LYKJ[2019]31), the Scientific Research Programs for High-level Talents Start-up Fund of Jinling Institute of Technology (jit-b-202008).

${ }^{+}$These authors contributed equally.

Conflict of interest: The authors declare that they have no conflict of interest. 
in plant molecular breeding and biotechnology (Da Silva et al. 2019). However, it should be stated that the ability to rapidly propagate plants in vitro has its own challenges such as different genotypic characteristics, explant survival, phytohormones, culture medium composition, and culture conditions (Dobránszki and Da Silva 2010, Magyar-Tábori et al. 2010, Da Silva et al. 2019).

With E. bungeanus immature stems, Li and Shi (2009) have successfully generated auxiliary buds and obtained callus tissues. In 2010, the optimum culture medium for E. bungeanus propagation was discovered and the explants were mature embryos (Zhang et al. 2010). To date, information on regeneration system from E. bungeanus leaves remains scant. The objective of the present study was to develop a rapid and high-efficient E. bungeanus protocol of vegetative propagation through tissue culture. We expect that the resulting protocol would be of interest to the development of E. bungeanus genetically engineered plants.

\section{Materials and methods}

Explants collection and sterilization: Two-year-old, wild-type E. bungeanus plants provided the material for this study. Plants were cultivated in a greenhouse and grown in pots (diameter $38 \mathrm{~cm}$, height $40.5 \mathrm{~cm}$ ) with 3:1 (v/v) peat soil (Klasmann-Deilmann 418\#, Geeste, Germany) and Perlite (particle size specification: $3 \sim 6 \mathrm{~mm}$, Altea, Lachine, Canada) and watered every three days without fertilizer. The greenhouse is located at the Jinling Institute of Technology's Horticultural Experimental Station (Nanjing, China). Young leaves (explants) were harvested from the upper branches, cleaned by $5 \%(\mathrm{~m} / \mathrm{v})$ washing powder (Tide, Guangzhou, China) solution, rinsed with tap water for $2 \mathrm{~h}$, and washed in $50 \mathrm{dm}^{3}$ tubes on a shaker with distilled water for $10 \mathrm{~min}$. After that, the leaves were soaked in $75 \%(\mathrm{v} / \mathrm{v})$ alcohol solution for $30 \mathrm{~s}$ and sterilized by $15 \%(\mathrm{~m} / \mathrm{v}) \mathrm{NaClO}$ solution. The $15 \% \mathrm{NaClO}$ solution sterilization time was determined through a range of sterilization experiments (sterilization times ranging from 1 to $7 \mathrm{~min}$, with $1 \mathrm{~min}$ increments, thus 7 treatment times). After immersion in the $15 \% \mathrm{NaClO}$ solution, leaves from each treatment time were rinsed by sterile water within $500 \mathrm{dm}^{3}$ glass beaker for $2 \mathrm{~min}$. Under the aseptic condition, the sterilized leaves were cut into small segments $(5 \times 5 \mathrm{~mm})$ (Fig. 1 Suppl.) and then placed on (Murashige and Skoog 1962; MS) medium. Each treatment was done in three replications, yielding totally 630 leaf explants. To examine the effects of sterilization time, the pollution rate and survival rate percentages were calculated as follows:

Pollution rate $=($ No. of explants polluted/No. of explants inoculated) $\times 100 \%[1]$

Survival rate $=($ No. of explants survived $/$ (No. of explants inoculated - No. of explants polluted) $) \times 100 \%$ [2]

Callus formation: The sterilized leaf explants were cultivated on basal MS medium (Murashige and Skoog 1962) containing $6.5 \mathrm{~g} \mathrm{dm}^{-3}$ agar and $30 \mathrm{~g} \mathrm{dm}^{-3}$ sucrose and adjusted to $\mathrm{pH}$ 5.8. In this medium, six combinations of different hormones (T1 - T6) were tested (Table 1). In these combinations, 6-benzylaminopurine (6-BA) concentration was fixed at $0.5 \mathrm{mg} \mathrm{dm}^{-3}$, while $\alpha$-naphthalene acetic acid (NAA) concentration varied from 0.05 to $0.5 \mathrm{mg}$ $\mathrm{dm}^{-3}$ (Table 1). Each of these hormonal combinations in medium was placed in 30 glass culture bottles $\left(250 \mathrm{dm}^{3}\right)$ and this process was replicated three times. Each bottle contained five pieces of leaf explants and was cultivated in tissue culture room for $21 \mathrm{~d}$ for callus induction. The incubation was conducted under red radiation $(\approx 660 \mathrm{~nm}$; an irradiance of $70 \mu \mathrm{mol} \mathrm{m} \mathrm{m}^{-2} \mathrm{~s}^{-1}$ 16-h photoperiod), and a temperature of $24 \pm 2{ }^{\circ} \mathrm{C}$. The induction rate of callus was calculated as (No. of induced calluses/No. of inoculated leaf explants) $\times 100 \%$ [3].

To evaluate callus growth state, the fresh and dry masses of the resulting calli were measured using 1/1000 electronic balance (Sartorius, Goettingen, Germany). To estimate the dry mass, calli were oven-dried at $105{ }^{\circ} \mathrm{C}$ for $30 \mathrm{~min}$, then at $60{ }^{\circ} \mathrm{C}$ for $3 \sim 4 \mathrm{~h}$ to a constant mass (BOXUN, Shanghai, China).

Differentiation of adventitious buds: Well-induced callus was cut into small pieces in the size of $0.8 \times 0.8$ $\times 0.8 \mathrm{~cm}^{3}$ and then placed on the MS medium containing one of the hormonal combinations for $20 \mathrm{~d}$ (Table 1). Each hormonal medium combination was placed in 90 bottles (one replicate 30 ) with a total of three replicates, and five small callus pieces were placed in each bottle. For adventitious buds differentiation, we utilized white radiation $\approx 730 \mathrm{~nm}$ (an irradiance of $110 \mu \mathrm{mol} \mathrm{m}^{-2} \mathrm{~s}^{-1} ; 16-\mathrm{h}$ photoperiod) and a temperature $24 \pm 2{ }^{\circ} \mathrm{C}$. The growth of adventitious buds was monitored every three days and the induction rate of adventitious buds was calculated as (No. of adventitious buds/No. of inoculated calluses) $\times 100 \%$ [4]. The length of adventitious buds was measured using Vernier caliper after pressing the samples flat.

Induction of adventitious roots: Adventitious buds in 1.5 $-1.8 \mathrm{~cm}$ length were selected and transferred into rooting medium for $20 \mathrm{~d}$. Two types of rooting medium $(1 / 2 \mathrm{MS}$ and MS medium) were selected for the induction of adventitious roots. The $1 / 2 \mathrm{MS}$ and MS media were separately coupled with NAA (concentration from 0.05 to $0.5 \mathrm{mg} \mathrm{dm}^{-3}$ ) and indole-3-butyric acid (IBA; concentration from 0.05 to $2.0 \mathrm{mg} \mathrm{dm}^{-3}$ ) (Table 1). Each hormonal combination medium was placed in 90 bottles (one replicate 30) with three replicates, and five adventitious buds were placed in each bottle. For adventitious roots induction, we used the same conditions as for bud induction. The growth was monitored every three days and the induction rate of adventitious roots from adventitious buds was calculated as (No. of rooted plantlets/No. of inoculated adventitious buds) $\times 100 \%$ [5]. A number of adventitious roots were counted after $20 \mathrm{~d}$, and their length was measured using Vernier caliper after pressing the samples flat.

Acclimatization of plantlets: After incubating the adventitious buds in the rooting medium (T1 combination) for $20 \mathrm{~d}, 150$ aseptic plantlets belonging to three replicates 
NING et al.

Table 1. Hormonal combinations of E. bungeanus tissue culture medium used in different growth stages.

\begin{tabular}{|c|c|c|c|c|c|}
\hline \multirow[t]{2}{*}{ Growth stages } & \multirow[t]{2}{*}{ Combinations } & \multicolumn{3}{|c|}{ Hormone concentration $\left[\mathrm{mg} \mathrm{dm}^{-3}\right]$} & \multirow[t]{2}{*}{ Medium types } \\
\hline & & $6-\mathrm{BA}$ & NAA & IBA & \\
\hline \multirow[t]{6}{*}{ Callus formation } & $\mathrm{T} 1$ & 0.5 & 0.05 & 0 & MS \\
\hline & $\mathrm{T} 2$ & & 0.1 & & MS \\
\hline & $\mathrm{T} 3$ & & 0.2 & & MS \\
\hline & $\mathrm{T} 4$ & & 0.3 & & MS \\
\hline & $\mathrm{T} 5$ & & 0.4 & & MS \\
\hline & T6 & & 0.5 & & MS \\
\hline \multirow[t]{6}{*}{ Adventitious bud differentiation } & $\mathrm{T} 1$ & 1 & 0.05 & 0 & MS \\
\hline & $\mathrm{T} 2$ & & 0.1 & & MS \\
\hline & $\mathrm{T} 3$ & & 0.3 & & MS \\
\hline & $\mathrm{T} 4$ & & 0.5 & & MS \\
\hline & T5 & & 0.7 & & MS \\
\hline & T6 & & 0.9 & & MS \\
\hline \multirow[t]{6}{*}{ Adventitious root induction } & $\mathrm{T} 1$ & 0 & 0.05 & 2 & $1 / 2 \mathrm{MS}$ \\
\hline & $\mathrm{T} 2$ & & 0.2 & 0.6 & $1 / 2 \mathrm{MS}$ \\
\hline & $\mathrm{T} 3$ & & 0.5 & 0.05 & $1 / 2 \mathrm{MS}$ \\
\hline & $\mathrm{T} 4$ & & 0.05 & 2 & MS \\
\hline & T5 & & 0.2 & 0.6 & MS \\
\hline & T6 & & 0.5 & 0.05 & MS \\
\hline
\end{tabular}

were successfully rooted. To acclimate these plantlets to natural environment, the glass bottles lids were removed in the tissue culture room for three days. Then the bottles with plantlets were placed in a greenhouse for three days. Subsequently, the roots of aseptic plantlets were rinsed by sterile water before planting in the plastic pots (diameter $10 \mathrm{~cm}$, height $9 \mathrm{~cm}$ ). A total of 150 plantlets (one replicate with 50) were cultivated in the peat soil mixed with Perlite in the ratio of $3: 1(\mathrm{v} / \mathrm{v})$, and then the plantlets were incubated in the greenhouse. After $14 \mathrm{~d}$, their survival rate was recorded.

Statistical analysis: Data were analyzed using IBM SPSS v. 21.0 statistic software. One-way analysis of variance (ANOVA) was used to determine the significant differences between treatments' means by Duncan's multiple comparison test $(P<0.05)$.

\section{Results}

To optimize the sterilization time of leaf explants, young leaves were divided into seven groups and were submerged in $15 \% \mathrm{NaClO}$ solution for different periods ranging from 1 to $7 \mathrm{~min}$ with 1 -min increments. The pollution rates of leaf explants sterilized for the first 4 sterilization treatments (1 to $4 \mathrm{~min}$ ) were $100,91.3,50.1$, and $33.5 \%$, respectively, while their survival rates were $0,8.7,49.9$, and $66.5 \%$, respectively. On the other hand, the pollution rates for the 6- and 7-min sterilization treatments were $0 \%$, while their survival rates were 40.3 and $32.4 \%$, respectively. Interestingly, the pollution rates and survival rates of the 5-min sterilization treatment were 0 and $100 \%$, respectively, suggesting that the 5-min sterilization time is the best (Fig. 1A).

Callus induction was evaluated using constant 6-BA concentration $\left(0.5 \mathrm{mg} \mathrm{dm}^{-3}\right)$ across 6 different NAA concentrations ranging from 0.05 to $0.5 \mathrm{mg} \mathrm{dm}^{-3}$ (Table 1). After $21 \mathrm{~d}$ of culture, a significant difference $(P<0.05)$ was observed towards increased NAA concentrations (Fig. 1B). The best rate of callus formation was observed at NAA $\left(0.5 \mathrm{mg} \mathrm{dm}^{-3}\right)$ and 6-BA $\left(0.5 \mathrm{mg} \mathrm{dm}^{-3}\right)$ hormonal combination reaching $100 \%$ (Fig. $1 B$ ), with callus fresh and dry masses of $0.174 \pm 0.041 \mathrm{~g}$ and $0.027 \pm 0.011 \mathrm{~g}$, respectively, representing 338.9 and $186.3 \%$ increase from T2 to T5 (Table 2). In view of the growth status of the calli (Fig. 1C-E), we determined that T6 combination represents the optimal medium for E. bungeanus calli induction from leaf explants (that is $\mathrm{MS}+0.5 \mathrm{mg} \mathrm{dm}^{-3}$ $\left.6-\mathrm{BA}+0.5 \mathrm{mg} \mathrm{dm}^{-3} \mathrm{NAA}\right)$.

Adventitious bud induction was evaluated using a constant 6-BA concentration of $1.0 \mathrm{mg} \mathrm{dm}^{-3}$ across 6 different NAA concentrations ranging from 0.05 and $0.9 \mathrm{mg} \mathrm{dm}^{-3}$ (Table 1, Fig. 2A). Among these the NAA concentration of $0.5 \mathrm{mg} \mathrm{dm}^{-3}$ produced the highest, adventitious bud induction rate reaching approximately $100 \%$ (Fig. $2 B$ ), with an average of $2.8 \mathrm{~cm}$ adventitious bud length as compared to other combinations. Thus, we concluded that the hormonal medium containing $1.0 \mathrm{mg} \mathrm{dm}^{-3} 6$-BA and $0.5 \mathrm{mg} \mathrm{dm}^{-3}$ NAA was the best for regenerating plants with green leaves and strong stems (that is $\mathrm{MS}+1.0 \mathrm{mg} \mathrm{dm}^{-3} 6-\mathrm{BA}+0.5 \mathrm{mg} \mathrm{dm}^{-3} \mathrm{NAA}$ ) (Fig. 2C). 

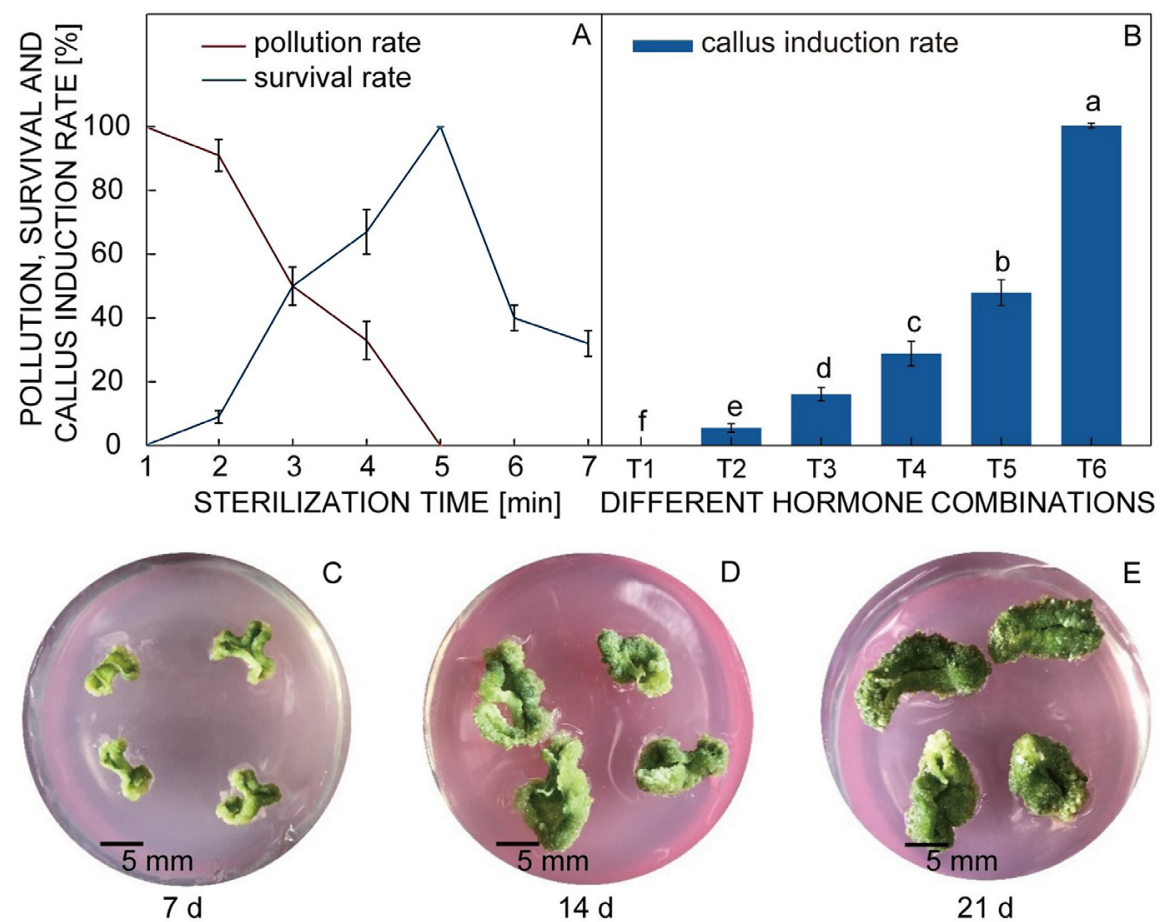

Fig. 1. Effect of different sterilization time and callus formation under different hormone combinations. $A$ - Pollution and survival rates of Euonymus bungeanus leaf explants with different sterilization time; $B$ - Callus induction rate under different hormonal combinations; $C, D, E$ - Callus differentiation at 7, 14, and $21 \mathrm{~d}$ on MS medium containing $0.5 \mathrm{mg} \mathrm{dm}^{-3} 6-\mathrm{BA}$ and $0.5 \mathrm{mg} \mathrm{dm}^{-3} \mathrm{NAA}$ (bar $\left.5 \mathrm{~mm}\right)$.

Table 2. Fresh and dry masses of E. bungeanus calli cultured under different hormonal combinations. Means \pm SDs, $n=3$; means followed by the same letter are not significantly different from each other's at $P<0.05$.

\begin{tabular}{lllll}
\hline Combinations & \multicolumn{2}{l}{$\begin{array}{l}\text { Hormone concentration }\left[\mathrm{mg} \mathrm{dm}^{-3}\right] \\
\text { 6-BA }\end{array}$} & Fresh mass $[\mathrm{g}]$ & Dry mass $[\mathrm{g}]$ \\
\hline T1 & 0.5 & 0.05 & --- & -- \\
T2 & 0.5 & 0.1 & $0.019 \pm 0.002 \mathrm{~cd}$ & $0.005 \pm 0.001 \mathrm{~cd}$ \\
T3 & 0.2 & $0.045 \pm 0.008 \mathrm{~cd}$ & $0.010 \pm 0.003 \mathrm{bcd}$ \\
T4 & 0.5 & 0.3 & $0.063 \pm 0.017 \mathrm{bc}$ & $0.014 \pm 0.004 \mathrm{bc}$ \\
T5 & 0.5 & 0.4 & $0.099 \pm 0.039 \mathrm{~b}$ & $0.019 \pm 0.007 \mathrm{ab}$ \\
T6 & 0.5 & 0.5 & $0.174 \pm 0.041 \mathrm{a}$ & $0.027 \pm 0.011 \mathrm{a}$ \\
\hline
\end{tabular}

To determine the optimum medium, sturdy adventitious buds were cut into small pieces and cultured in $1 / 2 \mathrm{MS}$ and MS coupled with different hormonal combinations (Table 1). Our results revealed that the rooting rate, number of adventitious roots, and length of adventitious roots showed significant difference when they were grown under NAA $\left(0.05,0.2,0.5 \mathrm{mg} \mathrm{dm}^{-3}\right)$ and IBA $(0.05$, $\left.0.6,2.0 \mathrm{mg} \mathrm{dm}^{-3}\right)$ in $1 / 2 \mathrm{MS}$ and $\mathrm{MS}$ medium $(P<0.05)$ (Fig. $3 A, B, C$ ). When the hormone combinations of NAA and IBA were the same, rooting rate, root number, and root length of the adventitious roots grown on $1 / 2 \mathrm{MS}$ medium (T1, T2, T3) produced better results than those grown on MS medium (T4, T5, T6). For instance, the rooting rates of the adventitious buds in T1, T2, and T3 were 99.7, 41.5, and $28.2 \%$, respectively, while the rooting rates of the adventitious buds in T4, T5, and T6 were 36.0, 12.6, and $0 \%$, respectively (Fig. $3 A$ ). These results indicated that $1 / 2 \mathrm{MS}$ medium containing different concentrations of NAA and IBA effectively contributed to the adventitious root growth. Moreover, when NAA and IBA concentrations were 0.05 and $2.0 \mathrm{mg} \mathrm{dm}^{-3}$ (namely $\mathrm{T} 1$ ), the rooting rate was approximately $100 \%$, and an average number of adventitious roots of 15 was the greatest (Fig. $3 B$ ), and the length of adventitious roots was $7.5 \mathrm{~cm}$, representing the longest of all treatments (Fig. $3 C$ ). Additionally, the adventitious roots had a strong main root and abundant lateral roots (Fig. 3D,E). These results allowed us to conclude that T1 (that is $1 / 2 \mathrm{MS}+0.05 \mathrm{mg} \mathrm{dm}^{-3} \mathrm{NAA}+$ $2.0 \mathrm{mg} \mathrm{dm}^{-3}$ IBA) is the most suitable for adventitious roots growth.

To investigate the adaptability of the rooted plantlets to natural environmental condition, a total of 150 aseptic rooted plantlets grown in $\mathrm{T} 1\left(1 / 2 \mathrm{MS}+0.05 \mathrm{mg} \mathrm{dm}^{-3} \mathrm{NAA}\right.$ $+2.0 \mathrm{mg} \mathrm{dm}^{-3}$ IBA) for $20 \mathrm{~d}$ were transplanted into plastic pots in a greenhouse. Surprisingly, after $14 \mathrm{~d}$ of plantlets grown in pots, all survived the greenhouse environment, 


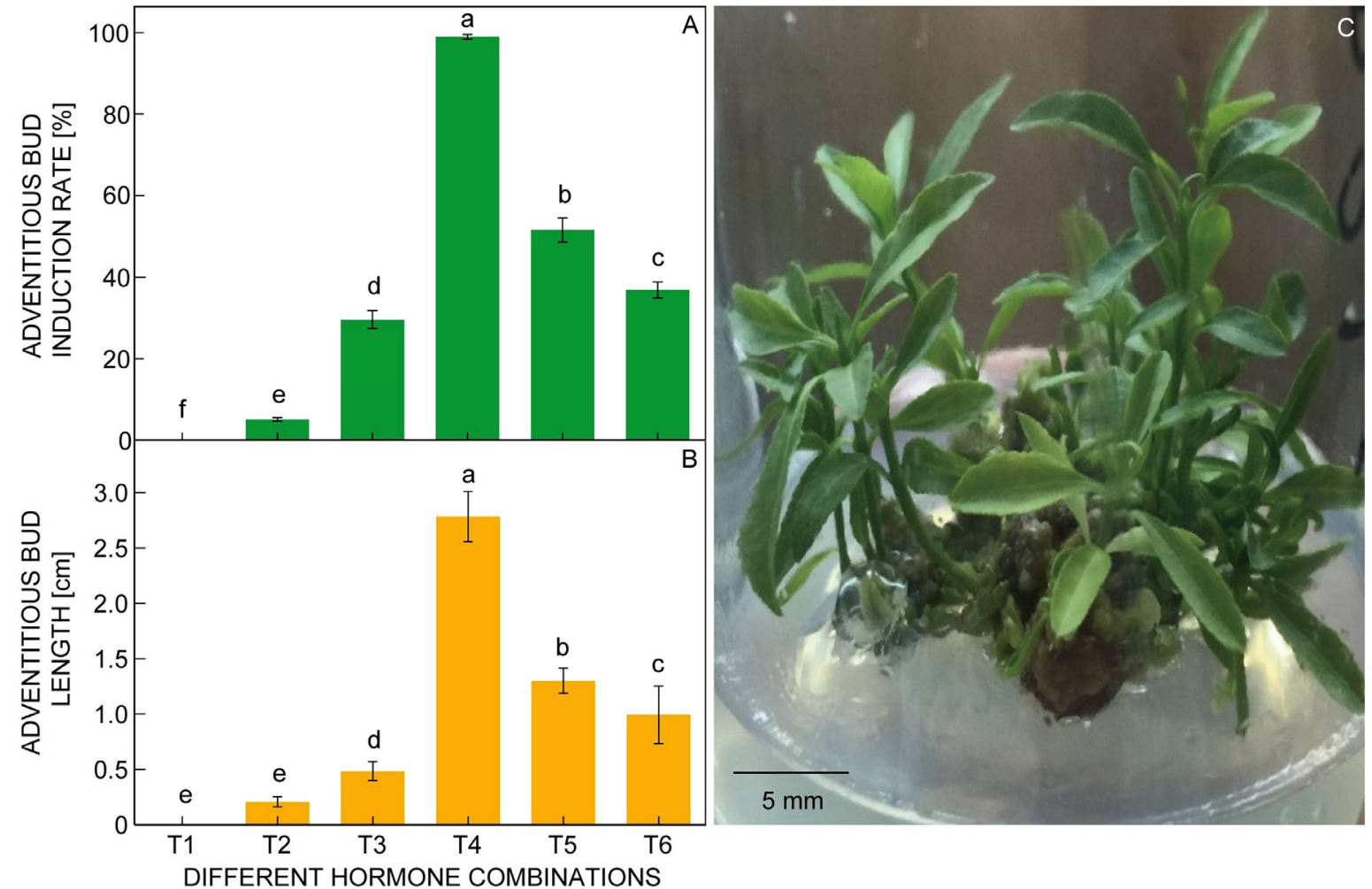

Fig. 2. Induction rate $(A)$ and length (B) of Euonymus bungeanus adventitious buds under different hormonal combinations. $C$ - Growth of adventitious buds in T4 medium after $20 \mathrm{~d}$ (bar $5 \mathrm{~mm}$ ).

indicating that these plantlets had excellent growth status (Fig. 2 Suppl.).

\section{Discussion}

Plant tissue culture is based on cell totipotency and has developed into a useful protocol for complete plant regeneration with great large-scale production potential (Shahzad et al. 2017, Lee and Pijut 2017). Successful plant tissue culture is dependent on the regeneration ability of different species, and also on variables, such as tissues or organs to develop into cloning, physiological age, growth stage, and position of explants directly or indirectly affecting the establishment of tissue culture (Cंosic et al. 2015, Raomai et al. 2015).

The selection of suitable explants, culture mediums, and hormonal treatments are the key factors in the success of plant tissue culture (Rout and Sahoo 2007). In woody plants, the leaves and petioles as explants, have a higher ability to undergo callus formation, as opposed to other explant types (Lee and Pijut 2017, Wei et al. 2017, Rusea et al. 2018, Hesami et al. 2019). In this study, the leaves of E. bungeanus were selected as explants and were sterilized by $\mathrm{NaClO}$ for a short period of time. Li et al. (2009) obtained auxiliary buds from E. bungeanus immature stems, which successfully grew. They further used the produced leaves as explants to induce the formation of callus, differentiation of adventitious buds, and the formation of adventitious roots (the process lasted $80 \mathrm{~d}$ ).
These authors achieved 70.9, 50.0, and $82.5 \%$ success in callus induction, adventitious bud differentiation, and rooting, respectively. By comparison, our E. bungeanus tissue culture system of callus induction by using leaves directly was more simple and efficient. Additionally, the entire timeframe needed for the whole culture cycle was reduced to about $20 \mathrm{~d}$. Therefore, it can be said that we have optimized the process and successfully produced the new, simple and rapid tissue culture propagation system for E. bungeanus.

A major challenge in plant tissue culture is to sterilize explants while maintaining their viability (Duan et al. 2016). To date, a wide range of surface disinfectants has been generally used for sterilizing explants, such as ethanol, mercuric chloride aqueous solution, $\mathrm{NaClO}$ solution (commercial bleach), calcium hypochlorite, hydrogen peroxide, and benzalkonium bromide solution (Ahmad et al. 2016, Mahmoud and Al-Ani 2016, Gochhayat et al. 2017, Nisa et al. 2019). NaClO solution has been the most widely used due to its high efficacy against bacteria and fungi (Yildiz and Er 2002). The most effective leaf sterilization treatment in our study was $15 \% \mathrm{NaClO}$ for $5 \mathrm{~min}$. This treatment yielded pollution and survival rates of 0 and $100 \%$, respectively.

In the traditional plant tissue culture process using leaf explants, the formation of callus is followed by adventitious buds and adventitious roots (Pérez-Tornero et al. 2000, Agarwal 2015, Liu et al. 2016, Guan et al. 2018). The ability to initiate formation of callus is controlled by the hormonal composition of culture medium, nutrition and irradiance 


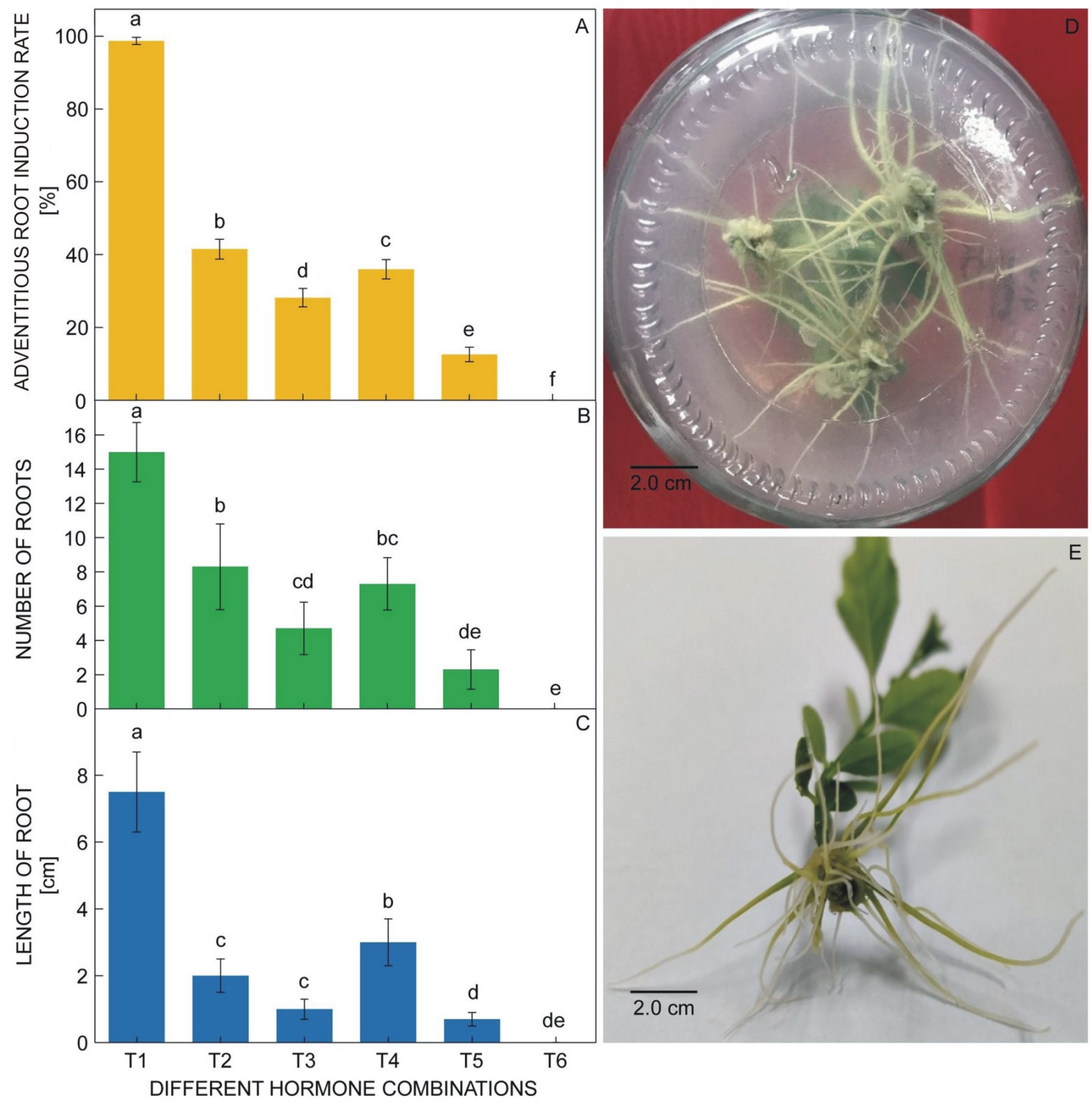

Fig. 3. Euonymus bungeanus adventitious roots induction and growth. $A$ - Adventitious roots induction rate under different hormonal combinations; $B$ - Number of adventitious roots under different hormonal combinations; $C$ - Length of adventitious roots under different hormonal combinations; $D, E$ - Growth of adventitious roots and plantlets in T1 madium after $20 \mathrm{~d}($ bar $2.0 \mathrm{~cm})$.

(Domir et al. 1992). Plant callus cultures play significant roles in agriculture and horticulture (Efferth 2019). Callus further differentiates into whole plantlet using appropriate culture media. In this study, the combination of 6-BA and NAA was used to induce callus formation. The callus induction rate approximately reached $100 \%$ when the concentration of these two hormones was fixed at $0.5 \mathrm{mg}$ $\mathrm{dm}^{-3}$. The visible external protuberances were observed and enlarged on the cuts between 7 and $21 \mathrm{~d}$, which might be caused by the high nutrient and hormone absorption efficiency at the cut edges (Sarwar and Skirvin 1997).

He et al. (2019) applied various concentrations of
6-BA in combination with NAA to establish an efficient protocol of callus proliferation in Chinese kale (Brassica oleracea var. alboglabra). He found that the best callus proliferation is in the MS medium supplemented with $2.5 \mathrm{mg} \mathrm{dm}^{-3} 6$-BA and $0.4 \mathrm{mg} \mathrm{dm}^{-3} \mathrm{NAA}$ after cultivation for $30 \mathrm{~d}$. In fact, the dosage and proportion of hormones is a critical factor influencing callus formation and subsequent differentiation. Mainly cytokinins and auxins added to various cultures effect the organogenesis (Yin et al. 2008). The ability of callus to differentiate into plantlets depends on the hormone concentration but different plants respond differently to the same hormone. He et al. (2019) used five 
times higher concentration of 6-BA than our study. This differences may be due to using different plant material. Wei et al. (2015) also found that 6-BA has a dominant role in promoting bud induction and proliferation in Bambusa ventricosa. Our result was similar to that of $\mathrm{He}$ et al. (2019), who reported that the combination of 6-BA and NAA had optimum callus proliferation of Chinese kale. In addition, with respect to plant callus induction, it is pointed out that the use of polychromatic radiation from light-emitting diode does not sufficiently effect the callus induction as the use of monochromatic radiation (Budiarto 2010). It was found that monochromatic red radiation could promote callus formation more effectively in Anthurium andraeanum leaves (Budiarto 2010). Hamada et al. (2009) also found that the induction rate of protocorm callus of Cymbidium finlaysonianum was the highest under red radiation. Liu et al. (2011) also reported that red radiation was beneficial to the induction and proliferation of protocorm callus of Oncidium hybridum. Our results showed that the callus induction from leaves under red radiation could reach $100 \%$ in E. bungeanus. Generally, the results varied in different plant species (Lin and Hsu 2004).

For the differentiation of adventitious buds from callus, our results showed that the concentrations of 1.0 $\mathrm{mg} \mathrm{dm}^{-3} 6$-BA and $0.5 \mathrm{mg} \mathrm{dm}^{-3}$ NAA was the most efficient treatment. Adventitious bud induction was nearly $100 \%$. A previous study showed that high concentrations of 6-BA could efficiently induce the formation of adventitious buds in Cavendish banana (Musa spp.) (Subramaniam et al. 2008). Another study showed that optimum hormone combination for differentiation of adventitious buds of Orostachys fimbriata was the MS medium supplemented with $1.5 \mathrm{mg} \mathrm{dm}^{-3}$ 6-BA and $0.2 \mathrm{mg} \mathrm{dm}^{-3}$ NAA (Liu et al. 2016). Similarly, the effect of 6-BA and NAA on adventitious bud formation in Lilium longiflorum cv. White fox was discovered, and the results demonstrated that the optimal medium for inducing adventitious buds is MS medium supplemented with $2.0 \mathrm{mg} \mathrm{dm}^{-3} 6-\mathrm{BA}$ and $0.1 \mathrm{mg} \mathrm{dm}^{-3}$ NAA. Under these conditions, the highest differentiation frequency reached $95.6 \%$ (Xi et al. 2012). All of the above results suggest that the combination of 6-BA and NAA contributes to the adventitious bud differentiation on MS medium.

NAA was also known as an effective phytohormone in inducing rooting from proliferated buds (Wei et al. 2015). A previous study indicated that $0.1 \mathrm{mg} \mathrm{dm}^{-3}$ NAA could efficiently promote the rooting process in Orostachys fimbriata tissue culture system (Liu et al. 2016). The combination of IBA + NAA, are found to be the most extensive hormone combination for rooting in tissue culture (Ullah et al. 2013). Our results showed that $1 / 2 \mathrm{MS}$ medium supplemented with $0.05 \mathrm{mg} \mathrm{dm}^{-3} \mathrm{NAA}$ and $2.0 \mathrm{mg} \mathrm{dm}^{-3}$ IBA was an excellent combination for rooting, and the induction rate of adventitious roots was close to $100 \%$. A propagation system for Garnem rootstock (almond $\times$ peach) was conducted and the highest root number was achieved by using $1 / 2 \mathrm{MS}$ medium with $2.0 \mathrm{mg} \mathrm{dm}^{-3}$ IBA (Erfani et al. 2017). In addition, the vigorous roots are also generated in $1 / 2 \mathrm{MS}$ medium supplemented with $0.5 \mathrm{mg} \mathrm{dm}^{-3}$
IBA (Zang et al. 2017). However, high induction rate of adventitious roots could be achieved by using MS media supplemented with $2.0 \mathrm{mg} \mathrm{dm}^{-3}$ IBA in an efficient in vitro tissue culture system for Crocus sativus (Zeybek et al. 2012). Therefore, different types of medium (MS or $1 / 2 \mathrm{MS}$ ) played distinct roles in plant rooting. Nevertheless, these findings repeatedly confirmed that IBA and NAA were required for the induction of adventitious roots.

\section{Conclusions}

We developed an efficient protocol for complete plant regeneration system through the organogenesis of adventitious buds from calluses using in vitro-derived leaf explants from the wild-type of E. bungeanus. This protocol will establish a basis for the realization of E. bungeanus large-scale production, as well as will serve as the foundation for the future genetic engineering.

\section{References}

Agarwal, M.: Tissue culture of Momordica charantia L. - J. Plant. Sci. 3: 24-32, 2015.

Ahmad, M., Nangyal, H., Imran, M., Ullah, F.: Optimization of protocol for surface sterilization and callus induction for three rice varieties. - Amer-Eurasian J. Agr. Environ. Sci. 16: $357-$ $361,2016$.

Budiarto, K.: Spectral quality affects morphogenesis on Anthurium plantlet during in vitro culture. - J. agr. Sci. 32: 234-240, 2010.

Cosic, T., Motyka, V., Raspor, M., Savić, J., Cingel, A., Vinterhalter, B., Vinterhalter, D., Trávníčková, A., Dobrev, P.I., Bohanec, B., Ninković, S.: In vitro shoot organogenesis and comparative analysis of endogenous phytohormones in kohlrabi (Brassica oleracea var. gongylodes): effects of genotype, explant type and applied cytokinins. - Plant Cell Tissue Organ Cult. 121: 741-760, 2015.

Da Silva, J.A.T., Gulyás, A., Magyar-Tábori, K., Wang, M.R., Wang, Q.C., Dobránszki, J.: In vitro tissue culture of apple and other Malus species: recent advances and applications. Planta 249: 975-1006, 2019.

Dobránszki, J., Da Silva, J.A.T.: Micropropagation of apple. Biotechnol. Adv. 28: 462-488, 2010.

Domir, S.C., Schreiber, L.R., Ichida, J.M., Eshita, S.M.: Effect of elm selection, explant source and medium composition on growth of Ophiostoma ulmi on callus cultures. - J. Environ. Hort. 10: 59-62, 1992.

Duan, Y.B., Zhao, F.L., Li, H., Zhou, Y.Y., Zhu, X.Y., Li, F.L., Chen, W.L., Xue, J.P.: Evaluation of aqueous chlorine dioxide for disinfecting plant explants. - In Vitro Cell Dev. Plant 52: 38-44, 2016.

Efferth, T.: Biotechnology applications of plant callus cultures. Engineering 5: 50-59, 2019.

Erfani, M., Miri, S.M., Imani, A.: In vitro shoot proliferation and rooting of Garnem rootstock as influenced by basal media, plant growth regulators and carbon sources. - Plant Cell Biotechnol. mol. Biol. 18: 101-109, 2017.

Gang, H.X., Li, R.H., Zhao, Y.M., Liu, G.F., Chen, S., Jiang, J.: Loss of GLK1 transcription factor function reveals new insights in chlorophyll biosynthesis and chloroplast development. - J. exp. Bot. 70: 3125-3138, 2019. 
Gochhayat, A.A., Beura, S., Subudhi, E.: Effect of surface sterilization time and plant bioregulators for callus formation in hybrid Lilium cv. Tresor. - Biosci. biotechnol. Res. Asia 14: 709-713, 2017.

Guan, Q.J., He, M.L., Ma, H.Y., Liao, X., Wang, Z.J., Liu, S.K.: Construction of genetic transformation system of Salix mongolica: in vitro leaf-based callus induction, adventitious buds differentiation, and plant regeneration. - Plant Cell Tissue Organ Cult. 132: 213-217, 2018.

Hamada, K., Shimasaki, K., Nishimura, Y., Egawa, H., Yoshida, K.: Effect of red fluorescent films on the proliferation of Cymbidium finlaysonianum Lindl. PLB cultured in vitro. Hort. Environ. Biotech. 50: 319-323, 2009.

He, Y., Liang, S., Zheng, H., Yuan, Q., Zhang, F., Sun, B.: Effects of plant growth regulators on callus proliferation of Chinese kale. - AIP Conference Proceedings. AIP Publishing 2058: 020023, 2019.

Hesami, M., Daneshvar, M.H., Yoosefzadeh-Najafabadi, M.: An efficient in vitro shoot regeneration through direct organogenesis from seedling-derived petiole and leaf segments and acclimatization of Ficus religiosa. - J. Forest. Res. 30: 807-815, 2019

Lee, J.H., Pijut, P.M.: Adventitious shoot regeneration from in vitro leaf explants of Fraxinus nigra. - Plant Cell Tissue Organ Cult. 130: 335-343, 2017.

Li, C.L., Shi, J.N.: [Tissue culture technique of Euonymus bungeanus.] -J. Anhui agr. Sci. 37: 14625-14626, 2009. [In Chinese].

Lin, M.-J., Hsu, B.: Photosynthetic plasticity of Phalaenopsis in response to different light environments. - J. Plant Physiol. 161: 1259-1268, 2004.

Liu, B.L., Zhang, Y., Zhang, K., Fang, H.Z., Zhang, X.M., Fu, R., Qiu, X.H., Xu, R.: The efficient tissue culture system of Orostachys fimbriata. - Agr. Sci. 7: 175-180, 2016.

Liu, J.Z., Cui, Q., Kang, Y.F., Meng, Y., Gao, M.Z., Efferth, T., Fu, Y.J.: Euonymus maackii Rupr. seed oil as a new potential non-edible feedstock for biodiesel. - Renew. Energy 133: 261267, 2019.

Liu, M.X., Xu, Z.G., Yang, Y., Feng, Y.J.: Effects of different spectral lights on Oncidium PLBs induction, proliferation, and plant regeneration. - Plant Cell Tissue Organ Cult. 106: $1-10,2011$

Magyar-Tábori, K., Dobránszki, J., Bulley, S.M., Da Silva, J.A.T., Hudák, I.: The role of cytokinins in shoot organogenesis in apple. - Plant Cell Tissue Organ Cult. 101: 251-267, 2010.

Mahmoud, S.N., Al-Ani, N.K.: Effect of different sterilization methods on contamination and viability of nodal segments of Cestrum nocturnum L. - Int. J. Res. Stud. Biosci. 4: 4-9, 2016.

Murashige, T., Skoog, F.: A revised medium for rapid growth and bioassays with tobacco tissue cultures. - Physiol. Plant. 15: 473-497, 1962.

Nisa, Z.U., Jan, S., Sajad, M.A., Shah, S.H., Farooq, G., Ali, H.: Micropropagation through apical shoot explants and morphogenic potential of different explants of Saussurea lappa: an endangered medicinal plant. - Pure appl. Biol. 8: 585-592, 2019.

Pérez-Tornero, O., Egea, J., Vanoostende, A., Burgos, L.: Assessment of factors affecting adventitious shoot regeneration from in vitro cultured leaves of apricot. - Plant Sci. 158: 61-70, 2000.

Raomai, S., Kumaria, S., Kehie, M., Tandon, P.: Plantlet regeneration of Paris polyphylla $\mathrm{Sm}$. via thin cell layer culture and enhancement of steroidal saponins in minirhizome cultures using elicitors. - Plant Growth Regul. 75:
341-353, 2015.

Rout, G.R., Sahoo, S.: In vitro selection and plant regeneration of copper-tolerant plants from leaf explants of Nicotiana tabacum L. cv. 'Xanthi'. - Plant Breed. 126: 403-409, 2007.

Rusea, I., Popescu, A., Isac, V., Sutan, A.N., Hoza, D. Adventitious shoot regeneration from petiole explants in black chokeberry (Aronia melanocarpa). - Scientific Papers, Series B, Horticulture 62: 83-91, 2018. Online ISSN 22861580, ISSN-L 2285-5653.

Sarwar, M., Skirvin, R.M.: Effect of thidiazuron and 6-benzylaminopurine on adventitious shoot regeneration from leaves of three strains of McIntosh apple (Malus $\times$ domestica Borkh.) in vitro. - Sci. Hort. 68: 95-100, 1997.

Shahzad, A., Sharma, S., Parveen, S., Saeed, T., Shaheen, A., Akhtar, R., Yadav, V., Upadhyay, A., Ahmad, Z.: Historical perspective and basic principles of plant tissue culture. Plant Biotechnology: Principles and Applications. - Springer, Singapore 2017.

Smith, C.C., Jernstedt, J.A.: In vitro development of adventitious shoots in Euonymus alatus (Celastraceae). - Scientia hort. 41: 161-169, 1989.

Song, H., Ding, G.G.Q.E.: [Study on influence factors of seed germination of Euonymus bungeanus.] - Seed 32: 87-88, 2013. [In Chinese]

Subramaniam, S., Rathinam, X., Poobathy, R., Sinniah, U.: In vitro production of multiple bud clumps (Mbcs) from Cavendish banana cultivar Brasilian (AAA). - Amer.-Eurasian J. Sustainable Agr. 2: 300-307, 2008.

Ullah, Z., Abbas, S.J., Naeem, N., Lutfullah, G., Malik, T., Khan, M.A.U., Khan, I.: Effect of indolebutyric acid (IBA) and naphthaleneacetic acid (NAA) plant growth regulators on Mari gold (Tagetes erecta L.). - Afr. J. agr. Res. 8: 4015-4019, 2013.

Wang, X.X., Wang, B.F., Zhao, G.H.: Rapid roots in cuttings of Euonymus bungeanus. - China Flowers Hort. 6: 47, 2016.

Wei, F., Zhao, F., Tian, B.: In vitro regeneration of Populus tomentosa from petioles. - J. Forest Res. 28: 465-471, 2017.

Wei, Q., Cao, J.J., Qian, W.J., Xu, M.J., Li, Z.R., Ding, Y.L.: Establishment of an efficient micropropagation and callus regeneration system from the axillary buds of Bambusa ventricosa. - Plant Cell Tissue Organ Cult. 122: 1-8, 2015.

Xi, M.L., Sun, L.N., Qiu, S., Liu, J.J., Xu, J., Shi, J.S.: In vitro mutagenesis and identification of mutants via ISSR in lily (Lilium longiflorum). - Plant Cell Rep. 31: 1043-1051, 2012.

Xu, X.Y., Guo, X.M., Cai, J.G., Yin, W.L., Wang, H.F.: Rooting experiment of hardwood cuttings of Euonymus maackii. - J. Zhejiang A\&F Univ. 21: 353-356, 2004.

Yildiz, M., Er, C.: The effect of sodium hypochlorite solutions on in vitro seedling growth and shoot regeneration of flax (Linum usitatissimum). - Naturwissenschaften 89: 259-261, 2002.

Yin, L., Lan, Y., Zhu, L.H.: Analysis of the protein expression profiling during rice callus differentiation under different plant hormone conditions. - Plant mol. Biol. 68: 597-617, 2008.

Zang, Q.L., Jiao, Y.L., Guo, X.M., Zhuge, F., Yeh, K., Lin, X.C.: Callus induction and plant regeneration from lateral shoots of herbaceous bamboo Mniochloa abersend. - J. hort. Sci. Biotechnol. 92: 168-174, 2017.

Zeybek, E., Önde, S., Kaya, Z.: Improved in vitro micropropagation method with adventitious corms and roots for endangered saffron. - Cent. Eur. J. Biol. 7: 138-145, 2012.

Zhang, L.J., Wang, Q.E., Zhou, Q., Zhang, C.: Study of tissue culture of Euonymus bungeanus. - Northern Hort. 17: 141$143,2010$.

(C) The authors. This is an open access article distributed under the terms of the Creative Commons BY-NC-ND Licence. 